Article

\title{
Correlates of Social Competences among Polish Adolescents: Physical Activity, Self-Esteem, Participation in Sports and Screen Time
}

\author{
Agnieszka Koszałka-Silska ${ }^{1, *\left(\mathbb{D}, \text { Agata Korcz }^{2} \mathbb{D} \text { and Agata Wiza }\right.}{ }^{1}$ \\ 1 Department of Pedagogy, Poznan University of Physical Education, Królowej Jadwigi 27/39, \\ 61-871 Poznan, Poland; wiza@awf.poznan.pl \\ 2 Department of Didactics of Physical Activity, Poznan University of Physical Education, Królowej Jadwigi \\ 27/39, 61-871 Poznan, Poland; korcz@awf.poznan.pl \\ * Correspondence: koszalka@awf.poznan.pl
}

Citation: Koszałka-Silska, A.; Korcz, A.; Wiza, A. Correlates of Social Competences among Polish Adolescents: Physical Activity, Self-Esteem, Participation in Sports and Screen Time. Sustainability 2021, 13, 13845. https://doi.org/10.3390/ su132413845

Academic Editors: Ma Luisa Zagalaz Sánchez, Javier Cachón-Zagalaz, María Sánchez Zafra and Déborah Sanabrias Moreno

Received: 16 November 2021 Accepted: 14 December 2021 Published: 15 December 2021

Publisher's Note: MDPI stays neutral with regard to jurisdictional claims in published maps and institutional affiliations.

Copyright: (c) 2021 by the authors. Licensee MDPI, Basel, Switzerland. This article is an open access article distributed under the terms and conditions of the Creative Commons Attribution (CC BY) license (https:/ / creativecommons.org/licenses/by/ $4.0 /)$.

\begin{abstract}
Adolescents' social competences determine the effectiveness of social functioning. In the long term, a higher level of social competence increases readiness for university and increases the chance of achieving success in a professional career. The primary objective of this study is to examine the association between social competences and self-esteem, physical activity, screen time, and participation in sports among Polish adolescents. 106 adolescents completed the Social Competences Questionnaire (SCQ) and Rosenberg's Self-Esteem Scale (RSES), as well as selected questions from the Health Behavior in School Aged Children (HBSC). Analysis of the study variables showed a moderate statistically significant relationship between social competences and self-esteem $\left(r_{s}=0.55\right.$, $p<0.001)$. Statistical analysis also showed that adolescents who engage in moderate and vigorous physical activity (MVPA; $\geq 5$ days/week) have significantly higher levels of social competences than adolescents with lower MVPA $(Z=3.50, p<0.001)$. No significant statistical association was found between social competences and screen time, or participation in sport. Hierarchical multiple regression also suggested that higher self-esteem and engaging in moderate and vigorous physical activity is positively associated with higher social competences among adolescents. Adolescents' social competences are significantly associated with self-esteem and physical activity. The results can help those working with young people with social functioning difficulties in performing effective interventions and shaping policies.
\end{abstract}

Keywords: physical education; sport; physical activity; social competences; self-esteem; screen time; adolescents

\section{Introduction}

Social competences (SCs) of adolescents determine the effectiveness of social functioning [1]. In the long term, a higher level of SCs in adolescents increases readiness for university, increases the chance of achieving success in a professional career, and helps to build positive relationships, thus supporting mental health [2]. The mental health of adolescents is an object of interest for the World Health Organization, which recommends the development of SCs as a way to prevent suicide among adolescents [3]. There is a link between the underdevelopment of SCs in childhood and adolescence and the difficulties associated with entering adulthood and taking on new social roles [4]. Research also suggests that SCs deficits are positively associated with an increased likelihood of exhibiting behavioral problems among adolescents [5]. The conditions in which young people function are changing dynamically, and education should contribute to equipping individuals with the skills to better understand themselves and others, as well as to function in a changing world. SCs are identified as important goals of education [6,7].

The definition of SCs implies that they are "complex skills conditioning the effectiveness of coping with certain types of social situations, acquired by the individual in the 
course of social training" [1]. Coping in social situations is determined by a variety of specific skills, and SCs are therefore seen as a set of interrelated elements that individuals use to varying degrees depending on the circumstances in which they find themselves.

Researchers highlight the possibility of developing SCs through, among other things, participation in physical activity (PA) [8-11]. There are also reports of a positive association of self-esteem with PA [12-14] and doing sport [15,16], and an association between selfesteem and SCs [17] (p. 57). There are also studies highlighting the relationship between PA, screen time, and adolescent self-esteem [18].However, there are no studies that resolve which variables are most important in shaping the level of SCs. Investigating the links between SCs in youth and self-esteem, screen time, PA, and sport participation can provide concrete evidence that can help in the performance of effective interventions and the shaping of policies.

SCs are related to self-esteem [17] (p. 57). Higher self-esteem is associated with greater courage and comfort in establishing new relationships [19]. Higher self-esteem in adolescents is related to a belief in oneself having better SCs, as well as perceiving oneself as socially attractive in interpersonal contacts [19]. In contrast, adolescents with low SC levels are more likely to be rejected by their peers and to have reduced interpersonal contacts. These adolescents are also more likely to have fewer opportunities to develop their social competences $[19,20]$ and tend to have lower self-esteem [21,22]. It has been noted that adolescents with low self-esteem are more likely to choose solitude, which may be due to social and emotional disturbances in their development [23-26]. Research among adolescents shows that social problem-solving abilities and perceptions of social support are related to the prospect of higher self-esteem [27]. Teenagers with low self-esteem are less accepted by their peers, which increases the likelihood of separation from peers and loneliness $[26,28]$. In general, the ability to function in multiple social situations is related to self-esteem [29].

Research on the relationship between screen time and SCs in children and young people is inconsistent. Some studies highlight the role of screen time in establishing and maintaining social contacts [30]. A study of teenagers between the ages of 12 and 18 found that girls were more likely to use screen time to communicate with others, while boys were more likely to play passive games, watch videos, and use screen time for fun [31]. However, it is important to note that SCs are skills acquired in the course of social training, i.e., during social interaction [1]. According to research, teenagers aged 12-17 communicate most frequently via phones and text messages [32]. By choosing to communicate using 'screens', they may thus reduce the time spent on face-to-face communication [33], therefore reducing the opportunity to participate in social competences training.

According to guidelines proposed by the American Academy of Pediatrics, the maximum time spent in front of a screen should not exceed $2 \mathrm{~h}$ per day [34].The negative effects of sedentary time may result from the substitution of active forms of time spent in favor of screen time. There are studies that have shown a link between time spent in front of a screen and adverse health outcomes in young people [35-37].

Associations between SCs and moderate and vigorous physical activity (MVPA) were noted, although they were relatively weak [38]. PA is a prerequisite for the maintenance of physical [39,40] and mental health [41]. PA plays a particularly important role in shaping young people's lifestyles and habits, influencing their wellbeing [42] and representing an investment in their future health. As such, there are concerns about young people who do not meet PA guidelines of $60 \mathrm{~min}(1 \mathrm{~h})$ or more a day [39,40]. Although at least $60 \mathrm{~min}$ per day of moderate and vigorous physical activity (MVPA) is recommended, PA levels decrease during adolescence $[39,40]$, and sedentary behaviors increase, at the expense of mild PA [43]. A survey of 14-19 year-olds found a high prevalence of inadequate PA and spending time passively [44]. It has been estimated that over $80 \%$ of adolescents aged 13-15 years worldwide do not meet PA recommendations [45].

Young people who play sport have higher levels of SCs and better social relationships, as well as self-esteem and self-worth $[13,16,46-48]$. Various studies have shown that sport 
has an impact on the acquisition and development of SCs [49-51]. Regular involvement in sports activities during childhood and adolescence contributes to the acquisition of SCs such as cooperation, awareness of responsibility, building empathy, self-control, and leadership [52,53]. In addition, compared to youths who do not participate in sports, those who do report better self-control, more assertive behaviors, higher self-esteem, and are rated by their teachers as displaying greater SCs [54].

Other studies show that young people who participate in sports activities improve their teamwork abilities, as well as SCs, emotional skills, and initiative [51]. Research conducted among socially vulnerable youth showed that sports participation was positively related to pro-social behavior, subjective health, well-being, and a sense of coherence [55].

The literature provides information on the associations of SCs with self-esteem, screen time, PA, and sport participation. However, it is not clear which variables play the greatest role in shaping SCs. Establishing the relationship and identifying the most relevant predictors of SCs will allow the most relevant factors to emerge in the context of the development of SCs. This will enable the setting of recommendations for shaping the SCs of young people and increasing their chances of success in everyday life, education, their careers. Improving the SCs of young people will support their well-being and mental health.

Analysis of the relationship between SCs and PA, screen time, participation in sports, and self-esteem among Polish adolescents may be useful in constructing recommendations for teachers who want to enable the development of SCs. Findings from the study can also be used to help design future research, interventions, and programs aimed at developing SCs in Polish adolescents. To our knowledge, no studies have been conducted on Polish adolescents to address the examination of SCs and its relationship with PA, screen time, sports participation, and self-esteem. Therefore, the present study may provide a foundation for future research focused on this population.

The primary objective of this study is to examine the association between social competences and self-esteem, physical activity, screen time, and participation in sports among Polish adolescents. It was hypothesized that higher self-esteem, higher levels of PA, and engagement in sport would be positively associated with SCs among adolescents, while screen time would be negatively associated with SCs.

\section{Materials and Methods}

\subsection{Participants and Procedure}

A cross-sectional research design was used in this study to examine the correlates of social competences among Polish adolescents. The study group comprises 106 adolescents ( 84 boys and 22 girls) aged $15-16$ years old $(M=15.75 \pm 0.44)$. The study was based on convenience sampling. Only the teenagers whose parents gave written consent to their children's participation in the study took part in the research. Permission was also obtained to publish the research results. The full description and objectives of the study were presented to parents and teenagers. Participants took part voluntarily and signed informed consent forms. Only a complete set of data was used for the statistical analyses. Young people completed the questionnaires in a quiet environment during a physical education lesson. It took them $40 \mathrm{~min}$. The general characteristics of the participants are found in Table 1. 
Table 1. General characteristics of the participants $(N=106)$.

\begin{tabular}{|c|c|c|c|}
\hline Variables & & Total $n=106$ & \\
\hline Age $(M \pm S D)$ & & $15.75 \pm 0.44$ & \\
\hline \multicolumn{4}{|l|}{ Gender $(n / \%)$} \\
\hline Boys & 84 & & 79.2 \\
\hline Girls & 22 & & 20.8 \\
\hline \multicolumn{4}{|l|}{ Mother's education $(n / \%)$} \\
\hline Primary education & 4 & & 3.8 \\
\hline High education & 33 & & 31.1 \\
\hline Tertiary education & 69 & & 65.1 \\
\hline \multicolumn{4}{|l|}{ Father's education $(n / \%)$} \\
\hline Primary education & 2 & & 1.9 \\
\hline High education & 46 & & 43.8 \\
\hline Tertiary education & 57 & & 54.3 \\
\hline \multicolumn{4}{|l|}{$\begin{array}{l}\text { Perceived family wealth } \\
\qquad(n / \%)\end{array}$} \\
\hline Wealthy/rather wealthy & 38 & & 35.8 \\
\hline Average & 64 & & 60.4 \\
\hline Poor/rather poor & 4 & & 3.8 \\
\hline $\operatorname{SCQ}(M \pm S D)$ & & $162.32 \pm 27.86$ & \\
\hline $\operatorname{RSES}(M \pm S D)$ & & $27.53 \pm 6.20$ & \\
\hline \multicolumn{4}{|l|}{ HBSC } \\
\hline \multicolumn{4}{|l|}{$\operatorname{MVPA}(n / \%)$} \\
\hline MVPA $<5$ days/week & 79 & & 74.5 \\
\hline MVPA $\geq 5$ days/week & 27 & & 25.5 \\
\hline Screen time $(M \pm S D)$ & & $4.22 \pm 1.52$ & \\
\hline Participation in sports $(n / \%)$ & 38 & & 35.9 \\
\hline
\end{tabular}

Note: SCQ = Social Competences Questionnaire, RSES = Rosenberg Self-Esteem Scale, MVPA = moderate and vigorous physical activity, $M=$ Mean, $S D=$ Standard Deviation.

The study was conducted in accordance with the Declaration of Helsinki. The Local Bioethics Committee (Karol Marcinkowski University of Medical Sciences in Poznan) approved the study (decision no. 467/19). The teenagers were informed of the anonymity and voluntary nature of taking part in the study, as well as the confidentiality of the results and the impossibility of identifying individual data in the final report. Parents signed a written consent form for their children to participate in the study.

\subsection{Instruments}

2.2.1. Social Competences Questionnaire Version for Adolescents (SCQ)

The SCQ is a Polish questionnaire for measuring SCs in young people. SCQ allows the determination of the level of SCs [1], which are defined as skills that determine the effectiveness of an individual's functioning in multiple social situations. The coefficient alpha of this tool is 0.94 [1] (p.5), while the coefficient alpha calculated for this research was 0.95 .

The SCQ is a self-descriptive questionnaire, containing 90 affirmative sentences in infinitive form and referring to a variety of social tasks and activities. The respondent is asked to rate the effectiveness of their actions on a scale described by four adjectives: definitely (4) good, not bad (3), rather poor (2), definitely bad (1). 60 sentences are diagnostic items (concerning SCs, the score ranges from 60 to 240) and the rest are non-diagnostic items. The sample items are: "How well you would do if you had to deliver a paper in class", or "How well you would do if you had to speak in a larger group discussion".

\subsubsection{Rosenberg's Self-Esteem Scale (RSES)}

The Polish version of Rosenberg's Self-Esteem Scale [29] was used to study self-esteem. The questionnaire examines the level of global self-esteem. It contains 10 statements, of which five statements are formulated in a positive way and the rest in a negative way. Respondents answer on a four-point scale $(1=$ strongly disagree to $4=$ strongly agree) [22] 
An example statement is as follows: "Overall, I'm satisfied with myself". The scoring for positive sentences is reversed, allowing higher scores to be awarded in relation to higher self-esteem [22]. RSES is used to survey adolescents. The coefficient alpha for the Polish version is 0.81 [29], while the coefficient alpha calculated for the present sample was 0.90.

\subsubsection{The Health Behavior in School Aged Children (HBSC)}

Selected questions from the HBSC were used to examine the following independent variables: level of PA, participation in sport and time in front of a screen. Questions relating to socio-economic data were also used. The PA level was measured by the MVPA index [56]. MVPA is defined as the average number of days per week on which participants were engaged in various forms of PA for at least $60 \mathrm{~min}$, during which, in their subjective assessment, their heart rate increased and they breathed faster. The range of possible answers is 0-7 days per week. This question was included in the HBSC from a test by Prochaska et al. [57] The subjects answered 2 questions, which are as follows: Q1: How many days in the last 7 days have you been physically active for at least 60 min a day? Q2: During a normal week, on how many days are you physically active for at least $60 \mathrm{~min}$ a day? The formula used to calculate MVPA is as follows: MVPA $=(\mathrm{Q} 1+\mathrm{Q} 2) / 2$ where: $\mathrm{MVPA}=\mathrm{PA}$ ratio; $\mathrm{Q} 1$ = number of physically active days in the last 7 days; $\mathrm{Q} 2$ = number of physically active days in a normal week. Data on participation in sport were obtained from answers to the question, "Do you participate in organized activities in your free time? Organized activities are those that take place at a sports club, leisure center, or organization". The question refers to two categories of organized sports activities-individual and teamwith the option to answer 'yes' or 'no'. Respondents who answered 'yes' at least once were classified as participating in organized sports activities.

An independent variable-screen time-was estimated from the following question: "How many hours a day, in your free time, do you usually use your computer, tablet, or smartphone (chatting, using the Internet, sending emails, Twitter, Facebook, Instagram, watching videos, playing games, etc.)?" The amount of screen time was declared by the respondent separately for school days (P1) and weekends (P2). A screen-time index was calculated based on the following formula: Screen time $=(\mathrm{P} 1 \times 5+\mathrm{P} 2 \times 2) / 7$ where: Screen time $=\mathrm{P} 1=$ number of hours per day on school days, $\mathrm{P} 2=$ number of hours per day at the weekend. The screen time score is a weighted average of the entire week [58]. According to the guidelines of the American Academy of Pediatrics Committee on Public Education, maximum screen time should not exceed $2 \mathrm{~h}$ per day [34]. In this study, screen time results were divided into the following two categories: $<2 \mathrm{~h}$ per day and $\geq 2 \mathrm{~h}$ per day.

Questions on socioeconomic background were also used to characterize participants, including questions on age, family, wealth, and parental education.

\subsection{Statistical Analysis}

All statistical analyses were performed with Statistica 13.1 (StatSoft Polska sp. z o.o., 2021). The quantitative variables studied were presented by mean $(M)$ and standard deviation $(S D)$, while the qualitative variables were presented by count $(n)$ and percentage $(\%)$. The data were screened and checked against the assumptions of regression analysis. The Mann-Whitney $(Z)$ test was used to assess the statistical significance of the association between the independent variables and the SCQ, and of the independent variables between each other. Spearman's rank correlation coefficients $r_{s}$ were used to assess the significance and power of the relationships between variables, with a value of correlation strength as follows:_0.39 weak, 0.40-0.59 moderate, and _0.60 strong [59]. Pearson's chi-squared test was also used. A hierarchical multiple regression was conducted with SCs as a dependent variable in order to test the study hypothesis. Only the variables that correlated significantly with SCQ were included in the model. Significance was accepted as $p<0.05$ throughout the analysis. 


\section{Results}

\subsection{Preliminary Analysis}

The analysis of the studied variables showed that as social competences increase, the level of self-esteem of adolescents increases. This association is moderately statistically significant $\left(r_{s}=0.55, p<0.001\right)$. At the same time, statistical analysis showed that higher levels of social competences are found in people with higher MVPA $\geq 5$ days/week $(177.7 \pm 26.13)$ than in people with lower MVPA $<5$ days/week $(157.1 \pm 26.58)$. This difference is statistically significant $(Z=3.50, p \leq 0.001)$. There was no statistically significant association between SCs and screen time $\left(r_{s} \geq 0.01, p=0.999\right)$, nor any statistically significant variation with respect to participation in sport $(Z=-0.95, p=0.343)$. Spearman's rank correlation coefficient for SCQ, RSES, and screen time are presented in Table 2. Mann-Whitney (Z) U test results for SCQ, RSES, and screen time in relation to MVPA and sport participation are presented in Table 3. Pearson's chi-square test was used to examine differences between MVPA and Participation in sports. The results are statistically significant $\left(\mathrm{Chi}^{2}=6.12, p=0.013\right)$.

Table 2. Spearman's rank correlation coefficient for SCQ, RSES, and Screen time.

\begin{tabular}{cccc}
\hline Variable 1 & Variable 2 & $r_{s}$ & $p$ Value \\
\hline SCQ & RSES & 0.55 & $\leq 0.001$ \\
SCQ & Screen time & $<0.01$ & 0.999 \\
RSES & Screen time & 0.02 & 0.821 \\
\hline
\end{tabular}

Note: SCQ = Social Competences Questionnaire, RSES = Rosenberg Self-Esteem Scale.

Table 3. Mann-Whitney $U$ test (Z) for SCQ, RSES, and Screen time depending on MVPA and participation in sports.

\begin{tabular}{ccccc}
\hline \multirow{2}{*}{ Variable } & \multicolumn{3}{c}{ MVPA } & \multicolumn{2}{c}{ Participation in Sports } \\
\cline { 2 - 5 } & $\boldsymbol{Z}$ & $\boldsymbol{p}$ Value & $\boldsymbol{Z}$ & $\boldsymbol{p}$ Value \\
\hline SCQ & 3.50 & $\leq 0.001$ & -0.95 & 0.343 \\
RSES & -0.37 & 0.714 & -0.20 & 0.838 \\
Screen time & 1.27 & 0.216 & 2.02 & 0.041 \\
\hline
\end{tabular}

Note: SCQ = Social Competences Questionnaire, RSES = Rosenberg Self-Esteem Scale, MVPA = moderate and vigorous physical activity.

\subsection{Hierarchical Multiple Regression}

A hierarchical multiple regression model was built with SCs as a dependent variable, and is presented in Table 4 . The model included 2 independent variables that correlated significantly with SCs. In the first step, self-esteem was included in the model $\left(R^{2}=0.34\right.$ $\left.p \leq 0.001 ; F_{1,143}=52.35, p \leq 0.001\right)$. In the second step, MVPA was included in the model. The final model was significant and explained a considerable proportion of variance in global SC levels $\left(R^{2}=0.43 p \leq 0.001 ; F_{2,103}=38.00, p \leq 0.001\right)$.

Table 4. Regression analysis predicting SCQ $(N=106)$.

\begin{tabular}{ccccc}
\hline Variables & $\mathbf{R}^{\mathbf{2}}$ & $\mathbf{B}$ & $\mathbf{F}$ & $p$ Value \\
\hline Step 1 & 0.34 & & 52.35 & $\leq 0.001$ \\
RSES & & 0.58 & & $\leq 0.001$ \\
Step 2 & 0.43 & & 38.00 & $\leq 0.001$ \\
RSES & & 0.57 & & $\leq 0.001$ \\
MVPA & & 0.30 & & 0.0001 \\
\hline
\end{tabular}

Note: RSES= Rosenberg Self-Esteem Scale, MVPA = moderate and vigorous physical activity.

\section{Discussion}

The primary objective of this study is to examine the association between social competences and self-esteem, physical activity, screen time, and participation in sports 
among Polish adolescents. As a result of this study, the hypothesis was partially confirmed. This means that the SCs of young people are related to self-esteem and physical activity (physical activity level was determined based on the moderate and vigorous physical activity). In contrast, SCs are not related to screen time and participation in sports activities.

Based on the analysis of the results, two variables were identified whose relationship reached statistical significance: self-esteem and moderate and vigorous physical activity. When the association of the SCs with screen time and participation in sport was analyzed, there was no statistically significant association. The independent variables-self-esteem and moderate and vigorous physical activity — which were significantly associated with SCs were used to build a multivariate analysis model. Using a multivariate analysis model, the role of the self-esteem and moderate and vigorous physical activity variables, which correlate internally with each other, was determined, and their combined prediction of SCs appeared to explain SCs to a high degree.

The reported association of SCs with self-esteem confirms the findings of other studies, in which correlational analyses have shown that SCs were positively related to selfesteem $[29,60,61]$. The literature on adolescents provides numerous reports on the association of physical activity with mental health, self-esteem, and well-being [16,41,42], but the association of SCs with moderate and vigorous physical activity has not been sufficiently studied in this age group. Some empirical studies $[8,9,62]$ provide information about the effect of physical activity on SCs, such as the effect of a 4-week physical activity-based Positive Youth Development program that resulted in participants achieving higher levels of SCs [62]. Similar reports have also been reported in other physical activity-based intervention programs: the Physical Education Based on the Adventure Education Program [9] and the Cooperative Physical Education Program [8].

Adolescence makes a teenager vulnerable in the emotional and social spheres [63]. On the one hand, it is a time of intense achievement of social maturity and, on the other, a time of increased vulnerability to adverse environmental and social influences, which can lead to many behavioral and emotional problems [63].

The present study provides information on the statistically significant association of SCs with self-esteem and moderate and vigorous physical activity. Self-esteem and moderate and vigorous physical activity make substantial provisions for SCs. Discovering the intrinsic correlation of self-esteem and moderate and vigorous physical activity as predictors of SCs allows us to gain a better understanding of SCs and thus design more effective interventions to strengthen and develop the SCs of young people.

This study has several potentially important limitations. Firstly, the data were collected at one high school in Poznan. Results can thus not be generalized to the whole Polish adolescent population. Secondly, the analyzed data were obtained via self-reporting, which may be a source of considerable bias.

Research to date has not focused sufficiently on adolescents' SCs and their relationship with self-esteem and moderate and vigorous physical activity. Analogous studies were mostly conducted among children in early and late childhood [64,65]. However, it is young people who are going through a critical period of adolescence in terms of mental health and well-being and who are at greater risk of the negative consequences of unsatisfactory social relationships [63]. The results have important implications for future research examining these relationships in other populations of adolescents. Therefore, the study of adolescent SCs and the analysis of SC predictors provides information in the context of prevention and the design of remedial actions to protect or improve the mental health and well-being of adolescents.

The present results show the relationship of self-esteem, moderate and vigorous physical activity, and SCs. The majority of students do not meet physical activity recommendations [56], and for that reason physical education (PE) lessons are an important opportunity to be physically active [66]. Providing regular physical activity to students is a key objective of PE. It should be noted that the objectives of PE treat the student comprehensively and address a variety of aspects, from the teaching of motor competences 
to the development of personal and social competences [67].Therefore, it can be assumed that PE lessons are an appropriate opportunity for physical development, while at the same time enabling the development of SCs in adolescents. The results of this study also justify the implementation of intervention programs during PE lessons aimed at developing SCs $[8,9,62]$.

In light of the results presented, it can be assumed that PE lessons are a suitable opportunity for the development of SCs in adolescents, which have been neglected during the period of remote learning caused by the COVID-19 pandemic, limiting the possibility of their development [68].

\section{Conclusions}

Adolescents' SCs are significantly associated with self-esteem and physical activity. Combined prediction and self-esteem explain SCs to a significant extent. SCs determine the effectiveness of young people's social functioning and are therefore important in terms of building and maintaining relationships with parents, peers, educators, and, in the future, co-workers, which ultimately has significant implications for current and future well-being and life satisfaction. This study highlights the important role of self-esteem and physical activity in the prediction of adolescent SCs. Based on the present research, it can be assumed that strengthening youth self-esteem and ensuring youth physical activity will contribute to the development and improvement of youth SCs.

The results of this study may be particularly useful for PE teachers who want to work holistically with students and influence both the physical and social developmental spheres of adolescents.

The presented research findings revealing the relationship of SCs with self-esteem and physical activity of adolescents can provide valuable guidance for both researchers and educators working with young people, providing information on what factors support the formation of SCs. The present results may also be helpful for psychologists and educators working with young people with behavioral problems and difficulties in social functioning. More broadly, the findings provide concrete evidence that can help in performing effective interventions and shaping policies.

Author Contributions: Conceptualization, A.K.-S., A.W.; methodology, A.K.-S., A.K. and A.W.; formal analysis, A.W.; investigation, A.K.-S.; data curation, A.K.-S.; writing-original draft preparation, A.K.-S., A.K., A.W.; writing-review and editing, A.K., A.W.; visualization, A.W.; supervision, A.W.; project administration, A.K.-S. All authors have read and agreed to the published version of the manuscript.

Funding: This research received no external funding.

Institutional Review Board Statement: The study was conducted according to the guidelines of the Declaration of Helsinki and approved by the Institutional Review Board (or Ethics Committee) of the Medical University of Karol Marcinkowski in Poznan (decision no. 467/19 and date of approval 4 November 2019).

Informed Consent Statement: Informed consent was obtained from all subjects involved in the study.

Data Availability Statement: The data presented in this study are available on reasonable request from the corresponding author.

Acknowledgments: The authors would like to thank Magdalena Lewandowska for her work on the statistical analysis. The authors appreciate the cooperation with the Nicolaus Copernicus School of Communications in Poznan and thank the management, teachers, children, and parents for the opportunity to conduct the study.

Conflicts of Interest: The authors declare no conflict of interest. 


\section{References}

1. Matczak, A. Kwestionariusz Kompetencji Społecznych. II; Pracownia Testów Psychologicznych Polskiego Towarzystwa Psychologicznego: Warszawa, Poland, 2012; ISBN 978-83-60733-13-4.

2. Greenberg, M.T.; Domitrovich, C.E.; Weissberg, R.P.; Durlak, J.A. Social and Emotional Learning as a Public Health Approach to Education. Future Child. 2017, 27, 13-32. [CrossRef]

3. Suicide. Available online: https://www.who.int/news-room/fact-sheets/detail/suicide (accessed on 3 July 2021).

4. Brzezińska, A.; Appelt, K.; Ziółkowska, B. Psychologia Rozwoju Człowieka; GWP: Sopot, Poland, 2016.

5. Hukkelberg, S.; Keles, S.; Ogden, T.; Hammerstrøm, K. The Relation between Behavioral Problems and Social Competence: A Correlational Meta-Analysis. BMC Psychiatry 2019, 19, 354. [CrossRef]

6. Appelt, K.; Jabłoński, S. Miejsce Kompetencji Społeczno-Emocjonalnych w Edukacji Wczesnoszkolnej. Psychol. Wychowawcza 2017, 64-82. [CrossRef]

7. Opstoel, K.; Chapelle, L.; Prins, F.J.; De Meester, A.; Haerens, L.; van Tartwijk, J.; De Martelaer, K. Personal and Social Development in Physical Education and Sports: A Review Study. Eur. Phys. Educ. Rev. 2020, 26, 797-813. [CrossRef]

8. Goudas, M.; Magotsiou, E. The Effects of a Cooperative Physical Education Program on Students' Social Skills. J. Appl. Sport Psychol. 2009, 21, 356-364. [CrossRef]

9. Koszałka-Silska, A.; Korcz, A.; Wiza, A. The Impact of Physical Education Based on the Adventure Education Programme on Self-Esteem and Social Competences of Adolescent Boys. Int. J. Environ. Res. Public. Health 2021, 18, 3021. [CrossRef]

10. Weiss, M.R. Teach the Children Well: A Holistic Approach to Developing Psychosocial and Behavioral Competencies Through Physical Education. Quest 2011, 63, 55-65. [CrossRef]

11. Asensio-Ramon, J.; Álvarez-Hernández, J.F.; Aguilar-Parra, J.M.; Trigueros, R.; Manzano-León, A.; Fernandez-Campoy, J.M.; Fernández-Jiménez, C. The Influence of the Scout Movement as a Free Time Option on Improving Academic Performance, Self-Esteem and Social Skills in Adolescents. Int. J. Environ. Res. Public. Health 2020, 17, 5215. [CrossRef]

12. Nemček, D. Self-Esteem Analyses in People Who Are Deaf or Hard of Hearing: A Comparison between Active and Inactive Individuals. Phys. Act. Rev. 2017, 5, 95-104. [CrossRef]

13. Russo, G.; Nigro, F.; Raiola, G.; Ceciliani, A. Self-Esteem in Physically Active Middle School Students. J. Phys. Educ. Sport 2019, 19, 1984-1988. [CrossRef]

14. Ahmed, M.D.; Ho, W.K.Y.; Niekerk, R.L.V.; Morris, T.; Elayaraja, M.; Lee, K.-C.; Randles, E. The Self-Esteem, Goal Orientation, and Health-Related Physical Fitness of Active and Inactive Adolescent Students. Cogent Psychol. 2017, 4, 1331602. [CrossRef]

15. Nemček, D.; Kraček, S.; Peráčková, J. Rosenberg Self-Esteem Scale Analyses among Elite and Competitive Athletes, Recreational Athletes and Inactive Individuals. J. Phys. Educ. Sport 2017, 17, 2305-2310.

16. Sipos, E.; Jeges, S.; Tóth, Á. Sport, Sense of Coherence, and Self-Esteem among 16 and 17-Year-Olds. Eur. J. Ment. Health 2015, 10, 62-78. [CrossRef]

17. Dzwonkowska, I.; Lachowicz-Tabaczek, K.; Łaguna, M. Samoocena i Jej Pomiar. Polska Adaptacja Skali SES M. Rosenberga. Podręcznik; Pracownia Testów Psychologicznych Polskiego Towarzystwa Psychologicznego: Warszawa, Poland, 2008.

18. Hrafnkelsdottir, S.M.; Brychta, R.J.; Rognvaldsdottir, V.; Gestsdottir, S.; Chen, K.Y.; Johannsson, E.; Guðmundsdottir, S.L.; Arngrimsson, S.A. Less Screen Time and More Frequent Vigorous Physical Activity Is Associated with Lower Risk of Reporting Negative Mental Health Symptoms among Icelandic Adolescents. PLoS ONE 2018, 13, e0196286. [CrossRef] [PubMed]

19. Twenge, J.M.; Baumeister, R.F.; DeWall, C.N.; Ciarocco, N.J.; Bartels, J.M. Social Exclusion Decreases Prosocial Behavior. J. Pers. Soc. Psychol. 2007, 92, 56-66. [CrossRef] [PubMed]

20. Meral, S.; Ağır, M. Factors Affecting Social Exclusion, Friendship Quality, Social Competence and Emotion Management Skills and the Effect of Problem Behaviors on Related Characteristics in Adolescents. J. Educ. Train. Stud. 2019, 7. [CrossRef]

21. Trzesniewski, K.H.; Donnellan, M.B.; Moffitt, T.E.; Robins, R.W.; Poulton, R.; Caspi, A. Low Self-Esteem during Adolescence Predicts Poor Health, Criminal Behavior, and Limited Economic Prospects during Adulthood. Dev. Psychol. 2006, 42, 381-390. [CrossRef]

22. Rosenberg, M. Society and Adolescent Self-Image; Princeton University Press: New York, NY, USA, 1965.

23. Baumeister, R.F.; Campbell, J.D.; Krueger, J.I.; Vohs, K.D. Does High Self-Esteem Cause Better Performance, Interpersonal Success, Happiness, or Healthier Lifestyles? Psychol. Sci. Public Interest. J. Am. Psychol. Soc. 2003, 4, 141. [CrossRef]

24. Wang, J.M.; Duong, M.; Schwartz, D.; Chang, L.; Luo, T. Interpersonal and Personal Antecedents and Consequences of Peer Victimization across Middle Childhood in Hong Kong. J. Youth Adolesc. 2014, 43, 1934-1945. [CrossRef]

25. Yang, S.-Y.; Fu, S.-H.; Wang, P.-Y.; Lin, Y.-L.; Lin, P.-H. Are the Self-Esteem, Self-Efficacy, and Interpersonal Interaction of Junior College Students Related to the Solitude Capacity? Int. J. Environ. Res. Public. Health 2020, 17, 8274. [CrossRef]

26. Hong, F.-Y.; Chiu, S.-I.; Huang, D.-H.; Chiu, S.-L. Correlations Among Classroom Emotional Climate, Social Self-Efficacy, and Psychological Health of University Students in Taiwan. Educ. Urban Soc. 2020, 53, 446-468. [CrossRef]

27. Jankowiak, B.; Jaskulska, S.; Sanz-Barbero, B.; Waszyńska, K.; Claire, K.D.; Bowes, N.; Silva, E.; Neves, S.; Albaladejo-Blázquez, N.; Pyżalski, J.; et al. Will I Like Myself If You Hurt Me? Experiences of Violence and Adolescents' Self-Esteem. Sustainability 2021, 13, 11620. [CrossRef]

28. Antonopoulou, K.; Chaidemenou, A.; Kouvava, S. Peer Acceptance and Friendships among Primary School Pupils: Associations with Loneliness, Self-Esteem and School Engagement. Educ. Psychol. Pract. 2019, 35, 339-351. [CrossRef] 
29. Dzwonkowska, I.; Lachowicz-Tabaczek, K.; Łaguna, M. Skala samooceny SES Morrisa Rosenberga polska adaptacja metody. Psychol. Społeczna 2007, 2, 164-176.

30. Patterns of Adolescent Physical Activity, Screen-Based Media Use and Positive and Negative Health Indicators in the U.S. and Canada. Available online: https://www.ncbi.nlm.nih.gov/pmc/articles/PMC2705990/ (accessed on 21 October 2021).

31. Peiró-Velert, C.; Valencia-Peris, A.; González, L.M.; García-Massó, X.; Serra-Añó, P.; Devís-Devís, J. Screen Media Usage, Sleep Time and Academic Performance in Adolescents: Clustering a Self-Organizing Maps Analysis. PLoS ONE 2014, 9 , e99478. [CrossRef]

32. Lenhart, A. Teens, Smartphones \& Texting; Pew Research Center: Washington, DC, USA, 2012; p. 34.

33. Giedd, J.N. The Digital Revolution and Adolescent Brain Evolution. J. Adolesc. Health 2012, 51, 101-105. [CrossRef] [PubMed]

34. Education, C. Children, Adolescents, and Television. Pediatrics 2001, 107, 423-426. [CrossRef]

35. Carson, V.; Hunter, S.; Kuzik, N.; Gray, C.E.; Poitras, V.J.; Chaput, J.-P.; Saunders, T.J.; Katzmarzyk, P.T.; Okely, A.D.; Connor Gorber, S.; et al. Systematic Review of Sedentary Behaviour and Health Indicators in School-Aged Children and Youth: An Update. Appl. Physiol. Nutr. Metab. 2016, 41, S240-S265. [CrossRef]

36. Fang, K.; Mu, M.; Liu, K.; He, Y. Screen Time and Childhood Overweight/Obesity: A Systematic Review and Meta-Analysis. Child Care Health Dev. 2019, 45, 744-753. [CrossRef]

37. Hoare, E.; Milton, K.; Foster, C.; Allender, S. The Associations between Sedentary Behaviour and Mental Health among Adolescents: A Systematic Review. Int. J. Behav. Nutr. Phys. Act. 2016, 13, 108. [CrossRef]

38. Grasten, A.; Kokkonen, M.; Quay, J.; Kokkonen, J. Social Competence and Moderate to Vigorous Physical Activity of School-Aged Children through a Creative Physical Education Intervention. Adv. Phys. Educ. 2019, 1-16.

39. Nader, P.R.; Bradley, R.H.; Houts, R.M.; McRitchie, S.L.; O’Brien, M. Moderate-to-Vigorous Physical Activity from Ages 9 to 15 Years. JAMA J. Am. Med. Assoc. 2008, 300, 295-305. [CrossRef]

40. Dumith, S.C.; Gigante, D.P.; Domingues, M.R.; Kohl, H.W. Physical Activity Change during Adolescence: A Systematic Review and a Pooled Analysis. Int. J. Epidemiol. 2011, 40, 685-698. [CrossRef] [PubMed]

41. Doré, I.; Sylvester, B.; Sabiston, C.; Sylvestre, M.-P.; O’Loughlin, J.; Brunet, J.; Bélanger, M. Mechanisms Underpinning the Association between Physical Activity and Mental Health in Adolescence: A 6-Year Study. Int. J. Behav. Nutr. Phys. Act. 2020, 17, 9. [CrossRef] [PubMed]

42. Schneider, M.; Dunton, G.F.; Cooper, D.M. Physical Activity and Physical Self-Concept among Sedentary Adolescent Females: An Intervention Study. Psychol. Sport Exerc. 2008, 9, 1-14. [CrossRef] [PubMed]

43. Mitchell, J.A.; Pate, R.R.; Dowda, M.; Mattocks, C.; Riddoch, C.; Ness, A.R.; Blair, S.N. A Prospective Study of Sedentary Behavior in a Large Cohort of Youth. Med. Sci. Sports Exerc. 2012, 44, 1081-1087. [CrossRef] [PubMed]

44. Tenório, M.C.M.; de Barros, M.V.G.; Tassitano, R.M.; Bezerra, J.; Tenório, J.M.; Hallal, P.C. Physical activity and sedentary behavior among adolescent high school students. Rev. Bras. Epidemiol. Braz. J. Epidemiol. 2010, 13, 105-117. [CrossRef] [PubMed]

45. Hallal, P.C.; Andersen, L.B.; Bull, F.C.; Guthold, R.; Haskell, W.; Ekelund, U.; Lancet Physical Activity Series Working Group. Global Physical Activity Levels: Surveillance Progress, Pitfalls, and Prospects. Lancet Lond. Engl. 2012, 380, 247-257. [CrossRef]

46. Spruit, A.; Assink, M.; van Vugt, E.; van der Put, C.; Stams, G.J. The Effects of Physical Activity Interventions on Psychosocial Outcomes in Adolescents: A Meta-Analytic Review. Clin. Psychol. Rev. 2016, 45, 56-71. [CrossRef]

47. D'Anna, C.; Rio, L.; Paloma, F.G. Competitive Sport and Self-Concept in Adolescent. J. Hum. Sport Exerc. 2015, 10. [CrossRef]

48. Howie, L.D.; Lukacs, S.L.; Pastor, P.N.; Reuben, C.A.; Mendola, P. Participation in Activities Outside of School Hours in Relation to Problem Behavior and Social Skills in Middle Childhood. J. Sch. Health 2010, 80, 119-125. [CrossRef] [PubMed]

49. Gould, D.; Carson, S. Life Skills Development through Sport: Current Status and Future Directions. Int. Rev. Sport Exerc. Psychol. 2008, 1, 58-78. [CrossRef]

50. Holt, N.L.; Neely, K.C.; Slater, L.G.; Camiré, M.; Côté, J.; Fraser-Thomas, J.; MacDonald, D.; Strachan, L.; Tamminen, K.A. A Grounded Theory of Positive Youth Development through Sport Based on Results from a Qualitative Meta-Study. Int. Rev. Sport Exerc. Psychol. 2017, 10, 1-49. [CrossRef] [PubMed]

51. Gould, D.; Flett, R.; Lauer, L. The Relationship between Psychosocial Developmental and the Sports Climate Experienced by Underserved Youth. Psychol. Sport Exerc. 2012, 13, 80-87. [CrossRef]

52. Shachar, K.; Ronen-Rosenbaum, T.; Rosenbaum, M.; Orkibi, H.; Hamama, L. Reducing Child Aggression through Sports Intervention: The Role of Self-Control Skills and Emotions. Child. Youth Serv. Rev. 2016, 71, 241-249. [CrossRef]

53. Perron-Gélinas, A.; Brendgen, M.; Vitaro, F. Can Sports Mitigate the Effects of Depression and Aggression on Peer Rejection? J. Appl. Dev. Psychol. 2017, 50, 26-37. [CrossRef]

54. Findlay, L.C.; Coplan, R.J. Come out and Play: Shyness in Childhood and the Benefits of Organized Sports Participation. Can. J. Behav. Sci. Rev. Can. Sci. Comport. 2008, 40, 153-161. [CrossRef]

55. Super, S.; Hermens, N.; Verkooijen, K.; Koelen, M. Examining the Relationship between Sports Participation and Youth Developmental Outcomes for Socially Vulnerable Youth. BMC Public Health 2018, 18, 1012. [CrossRef]

56. Bull, F.C.; Al-Ansari, S.S.; Biddle, S.; Borodulin, K.; Buman, M.P.; Cardon, G.; Carty, C.; Chaput, J.-P.; Chastin, S.; Chou, R.; et al . World Health Organization 2020 Guidelines on Physical Activity and Sedentary Behaviour. Br. J. Sports Med. 2020, 54, 1451-1462. [CrossRef]

57. Prochaska, J.J.; Sallis, J.F.; Long, B. A Physical Activity Screening Measure for Use With Adolescents in Primary Care. Arch. Pediatr. Adolesc. Med. 2001, 155, 554-559. [CrossRef] 
58. Małkowska-Szkutnik, A.; Mazur, J. Report HBSC Medycyna Szkolna Instytut Matki i Dziecka; Tenical Reports; Instytut Matki i Dziecka: Warszawa, Poland, 2018.

59. Schober, P.; Boer, C.; Schwarte, L.A. Correlation Coefficients: Appropriate Use and Interpretation. Anesth. Analg. 2018, 126, 1763-1768. [CrossRef]

60. Riggio, R.E.; Throckmorton, B.; DePaola, S. Social Skills and Self-Esteem. Personal. Individ. Differ. 1990, 11, 799-804. [CrossRef]

61. Impact of Social Skills Training on Self-Esteem among Male and Female Adolescent Students ProQuest. Available online: https: / / www.proquest.com/openview / adf5dd9f590d882508cb46587bb57afd/1?pq-origsite=gscholar\&cbl=2032133 (accessed on 22 October 2021).

62. Ullrich-French, S.; McDonough, M.H.; Smith, A.L. Social Connection and Psychological Outcomes in a Physical Activity-Based Youth Development Setting. Res. Q. Exerc. Sport 2012, 83, 431-441. [CrossRef]

63. Adolescent Mental Health. Available online: https://www.who.int/news-room/fact-sheets/detail/adolescent-mental-health (accessed on 31 August 2021).

64. Carson, V.; Lee, E.-Y.; Hesketh, K.D.; Hunter, S.; Kuzik, N.; Predy, M.; Rhodes, R.E.; Rinaldi, C.M.; Spence, J.C.; Hinkley, T. Physical Activity and Sedentary Behavior across Three Time-Points and Associations with Social Skills in Early Childhood. BMC Public Health 2019, 19, 27. [CrossRef] [PubMed]

65. Hinkley, T.; Brown, H.; Carson, V.; Teychenne, M. Cross Sectional Associations of Screen Time and Outdoor Play with Social Skills in Preschool Children. PLoS ONE 2018, 13, e0193700. [CrossRef] [PubMed]

66. Meyer, U.; Roth, R.; Zahner, L.; Gerber, M.; Puder, J.J.; Hebestreit, H.; Kriemler, S. Contribution of Physical Education to Overall Physical Activity. Scand. J. Med. Sci. Sports 2013, 23, 600-606. [CrossRef] [PubMed]

67. NASPE Publications. Moving into the Future: National Standards for Physical Education, 2nd ed.; NASPE Publications: Reston, VA, USA, 2004; ISBN 978-0-88314-909-6.

68. Burgess, S.; Sievertsen, H.H. Schools, Skills, and Learning: The Impact of COVID-19 on Education. VoxEU.org. 2020. Available online: https:/ / voxeu.org/article/impact-covid-19-education (accessed on 14 December 2021). 